\title{
効率的な干渉判定による板金の曲げ手順の 高速な生成アルゴリズム*
}

\author{
安倍宏 之乾正知***
}

A Fast Bending Sequencing Algorithm of Sheet Metal Parts by Efficient Detection of Collisions

Hiroyuki ABE and Masatomo INUI

In the sheet metal part manufacturing, bending is the most commonly used to realize sufficient rigidity and to obtain a part of desired shape to perform a certain function. Feasible bending sequences of a sheet metal part can be determined by successively applying bending simulations to the geometric model of the part. This simulation based method is computationally expensive because huge number of sequences must be explored if a part with many bending portions is given. In this paper, the authors propose a method to accelerate the simulation based sequencing method. Complicate parts with many bending portions usually have rather small number of feasible sequences because other sequences cause self interferences or collisions with tools in the bending operation. Our method reduces the computation cost by efficiently detecting such interferences and collisions in the early stage of the sequencing process. The collision information record is introduced which enables multiple use of the collision check result computed in the prior process. The proposed method is implemented and an experimental bending sequencing program is demonstrated. This program can derive all feasible bending sequences of complex sheet metal parts in an interactive speed.

Key words: efficient collision detection, bending process planning

1.はじめに

多くの板金裂品は，板金を $\mathrm{V}$ 字型や $\mathrm{L}$ 字型の金型に固定しプレ スする曲げ加工により弊造される 4$)$. 図 1 にV 字型の金型とパン チを用いた加工例を示す，板金憋品の憋造工程を自動決定するため には、製品の適切な曲げ手順を計算する機能が不可欠である，板金 幣品の造に最も悪影霓を与えるのは，加工中の板金の自己干涉や 板金と工具の干渉である.そこで本研究では，板金弊品の幾何モデ ルに基づいて，干渉を生じないすべての曲げ手順を計算する問題を 考える. 得られた手順に基づいて，加工の難易度の評価や加工精度 の検証などを行うことで，品の最適な曲け手順を決定できる．現 場の技術者が工程設計する際にも，紙上で同様の作業を行ってい

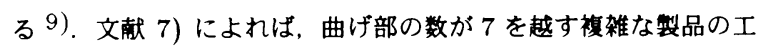
程設計には，熟練した技術者でも数日を要する.

可能な曲げ手順を計算する問題は，弊品の全曲げ部を展開した状 態の幾何モテルを作成し，これに曲げ加エのシミュレーションを順 に施し，干涉の生じない手順をすべて探索すれば解くことができ る. 曲け部の数を $n$ とすると, 可能な曲げ手順は最大 $n$ ! 通り存在 するので，素朴なアルコリズムでは，曲け部の多い製品の処理時間 が嶂大なものになってしまう，第者らは，曲げ加エシミュレーショ ンの際に彆品に指定されている公差を評価し，公差が满たされな い手順を途中で破裹することで探索空間を維小するアルコリズム を提案した ${ }^{2)}$ ．曲け部には比較的楥やかな公差が指示されるの で，公差評価だけでは探索空間はあまり樎小されない，Wang と Bourne は，板金の特徵的な形状に基づくヒューリスティックな 制約とコスト評価を組み合わせることで，探索空間を䑾小してい る 7)。同様の手法は岡田らも提案している 3 )。しかし板金の場合 には，形状特徽と曲け手順の関保付けが困難な場合が多いため。こ のアルコリズムでは正しい手順を見落とすことがある.

\footnotetext{
*原稿受付平成 9 年 3 月 21 日

**学生会員茨城大学工学部（日立市中成沢町 4-12-1）

…正会员茨城大学工学部
}

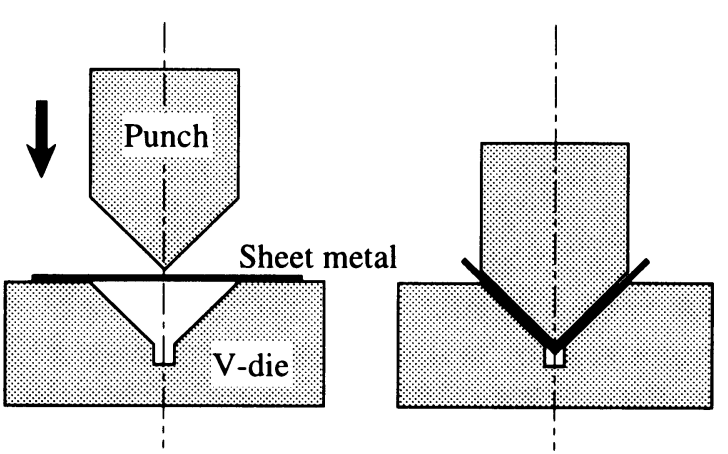

Fig.1 Bending method with a V-shaped die and a punch

人工知能の分野では，探索に要するコストを低減するために，階 屋的な探索や知的なバックトラック, 過去の探索結果の再利用など の技術が開発されている 6)。しかし曲け手順の生成問題では, こ れらの技術は効果が期待できない. たとえばこの問題では, 解の探 索空間に階㾍性を見つけることができない，またこのような作業手 順を決定する問題では，ルールの適用順序が重要なため, ATMS のような矛盾するルールの組合せに基づいて無䭾なバックトラック を省く技術は，うまく機能しない．曲げシミュレーションを実行す ると板金モデルが変形するため, 過去に萁出された探索結果をその まま再利用することも難しい.

機械製品の組立てプラン生成の分野では，探索方法の改善ではな く, 探索中に最も時間を要する部品間の干渉判定を効率化すること で，高速処理を実現する技術が注目されている 8)．曲げ部の多い 複雑な板金彆品ほど，加工中に板金や工具間に干渉を生じやすいの で, 曲げ部の数が増えても可能な曲げ手順はそれほど爆発的には增 加しない. したがって組立てプランの生成問題と同様に, これらの 干渉の有無を効率的に判定し探索空間の縮小に利用すれば, 問題解 決のための手間をかなり削隇できる.この考え方に基づいて，板金 弊品の可能なすべての曲げ手順を高速に生成するアルコリズムを開 
発したので報告する．実際にプログラムを作成し，計算実験により アルコリススムの有効性を検証した. なお本研究では, 板金の加工法 として，V 字型の工具を用いて直線にそって折り曲げる方法のみ を考え，丸め加工やカール加工などの特殊な方法は考虑しない，ま た，既に展開状態に切り拔かれた板金を曲げていくだけの工程を想 定し，曲げ加工と抜き加工を併用するような作業は考えない．

次節では，本研究で用いた板金憋品の幾何モデルについて説明す る. 3 節では, 曲げ手順の生成アルゴリズムの概要を説明する，4 節では，板金や曲げ加工の幾何的な性質などを利用して，干渉判定 を効率的におこなう手法を示す，5節では，試作した曲げ手順生成 プログラムによる計算実験の結果を紹介する.

\section{2. 板金紫品の濰何モデル}

曲げ加工中の板金の自己干渉や工具との干渉を判定するために は, 加工にともなう板金の変形を正しく扱う必要がある. 本節で は，曲げによる変形を考虑した板金製品の幾何モテルについて説明 する.このモデルは文献 2）と 7) に基づいている.

\section{1 板金モデル}

直線にそった曲げ加エでは, 変形は加工力が作用する曲け軸の近 傍にのみ発生し, 残りの大部分の形状は変化しない。この曲げ加工 の特徵に基づいて，板金撆品を曲け軸の近傍と，それ以外の変形を 生じない板状の部分に分けてモデル化した. 曲け軸近傍の領域はご く狭いので, 干渉判定では無視できる. そこで曲げ加工による板金 蔽品の形状変化を, ある仮想的な軸周りを板状の薄い立体モデルが 回転移動することで近似した ${ }^{2}$ ).

曲け軸近傍では，板金の外側は引き延ばされる方向に，また内側 は圧樎される方向に応力が作用する ${ }^{1)}$ 。したがってこの部分の 断面を考えると, 応力が全く作用しない「中立面」とよばれる面 が存在する. この面上では変形が生じないことから, 中立面は加 工前の素材の長さを維持している．このことを考虑すると，仮想 的な回転軸 $A x$ は, 図 2に示す式を解くことで決められる. 中立 面の位置を示す保数 $k$ は板金の材質や厚さによって異なるが，通 常 $k=0.3$ 程度である. 図中の回転角が $\psi=0^{\circ}$ であれば展開状 態, $\quad \psi=180-\omega^{\circ}$ ( $\omega$ は曲げ角度) であれば曲げ加工された状 態が表現される.

以後の議論では，仮想的な回転軸をベンドとよび，板状の薄い立 体モデルをプレートとよぶ. 各ベンドの左右には 2 枚のプレートが 接続する．このベンドとプレートの接続関係はループを作らない． したがって板金モテル $\mathcal{S}$ は, プレートの集合 $\mathcal{P}=\left\{P_{i}\right\}$ と, そ れらを結合するベンドの集合 $\mathcal{B}=\left\{B_{i}\right\}$ から棰成される木構造 $\mathcal{S}=(\mathcal{P}, \mathcal{B})$ となる $\left.{ }^{7}\right)$.

\section{2 座模変換による曲げ加工の扱い}

板金モテル $\mathcal{S}=(\mathcal{P}, \mathcal{B})$ の形状を表現するためには，モデルを構 成するすべてのプレート $\forall P_{i} \in \mathcal{P}$ を，基準座標系 $F_{W}$ 中の適切な 場所に配置すれば良い，そこで各プレート $P_{i}$ 上にプレート固有の 座標系 $F_{P_{i}}$ を定義し， $F_{W}$ における $F_{P_{i}}$ の位置姿勢を表す同次 座標変換 $\mathbf{H}_{P_{i}}^{W}$ を与えることで $P_{i}$ を位置決めする ${ }^{5)}$ ， ベンド $B_{i}$ に 2 枚のプレート $P_{j}$ と $P_{k}$ が接続しているだけの単純な構造の板 金モデルを用いて, 各プレートの座標変換の計算手順を説明する.

まず $B_{i}$ が展開状態の場合を考える. プレートと同様に, ベンド $B_{i}$ にも固有の座標系 $F_{B_{i}}$ を与える. ただし $F_{B_{\imath}}$ は, その $z$ 軸が 仮想的な回転軸と一致するように定義されている． $P_{j}$ の座標系 $F_{P_{j}}$ における， $B_{i}$ の座標系 $F_{B_{i}}$ の位置姿勢を表す同次座標変換 を $\mathbf{H}_{B_{i}}^{P_{j}}$ とする. 同様に $P_{k}$ の座標系 $F_{P_{k}}$ における， $F_{B_{i}}$ の位 置姿勢を表す座標変換を $\mathbf{H}_{B_{i}}^{P_{k}}$ とする，これら 2 つの座標変換は製

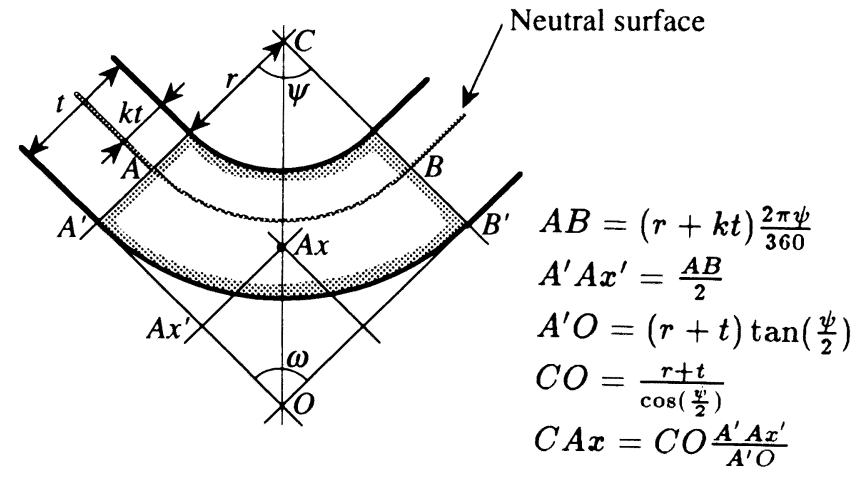

Fig.2 Definition of the centerline of bending rotation

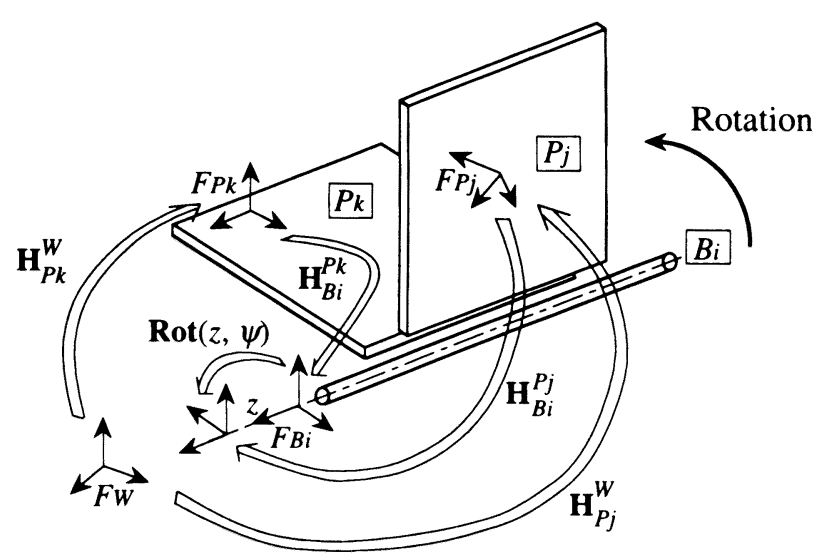

Fig.3 Spatial relationships between coordinate frames specified on a bend $B_{1}$ and its connecting plates $P_{j}$ and $P_{k}$

品の展開図から容易に得られる. $\mathbf{H}_{P_{j}}^{W}, \mathbf{H}_{P_{k}}^{W}, \mathbf{H}_{B_{i}}^{P_{j}}, \mathbf{H}_{B_{i}}^{P_{k}}$ の 間には以下の関係式が成り立つので, $\mathbf{H}_{P_{j}}^{W}$ か $\mathbf{H}_{P_{k}}^{W}$ のどちらかが 分かれば，他方の変換は式を変形することで計算できる.

$$
\mathbf{H}_{P_{j}}^{W} \mathbf{H}_{B_{i}}^{P_{j}}=\mathbf{H}_{P_{k}}^{W} \mathbf{H}_{B_{i}}^{P_{k}}
$$

次にベンド $B_{i}$ に曲げ加工が施され， $B_{i}$ に接続する 2 枚のプ レート $P_{j}$ と $P_{k}$ のなす角度が $\omega^{0}$ となった場合を考える. われわ れのモテルでは，この変形を $P_{j}$ （もしくは $P_{k}$ ）が， $B_{i}$ の座標 系 $F_{B_{i}}$ の $z$ 軸周りを $\psi=180-\omega^{\circ}$ 回転移動することで表現す る. $z$ 軸周りの回転変換を $\operatorname{Rot}(z, \psi)$ と書くことにすると，座標 変換間に以下の関係式が成り立つ（図3参照）

$$
\mathbf{H}_{P_{j}}^{W} \mathbf{H}_{B_{\mathfrak{i}}}^{P_{j}}=\mathbf{H}_{P_{k}}^{W} \mathbf{H}_{B_{i}}^{P_{k}} \operatorname{Rot}(z, \psi)
$$

したがって展開状態の場合と同様に， $\mathbf{H}_{P_{j}}^{W}$ か $\mathbf{H}_{P_{k}}^{W}$ のどちらかが 分かれば，他方の変換は式 (2) から計算できる.

一般の板金モテル $\mathcal{S}=(\mathcal{P}, \mathcal{B})$ は, プレートの集合 $\mathcal{P}$ とベンド の集合 Bをそれぞれ頂点と辺とする木構造である. そこでまず 1 枚 のプレート $P_{i} \in \mathcal{P}$ を選び， $\mathbf{H}_{P_{i}}^{W}$ として適切な座標変換を与える ことでその位置姿勢を確定する，次にベンドを介して $P_{i}$ に接続する 他のブレートをたどる. その際ベンドが展開状態であれば式 (1), 曲け状態であれば式 (2) を用いて，たどった先のプレートの位置姿 势を確定する. 以上の処理を，すべてのプレートをたどり終えるま で繰り返せば，任意の曲げ状態の板金彆品の形状が得られる。 


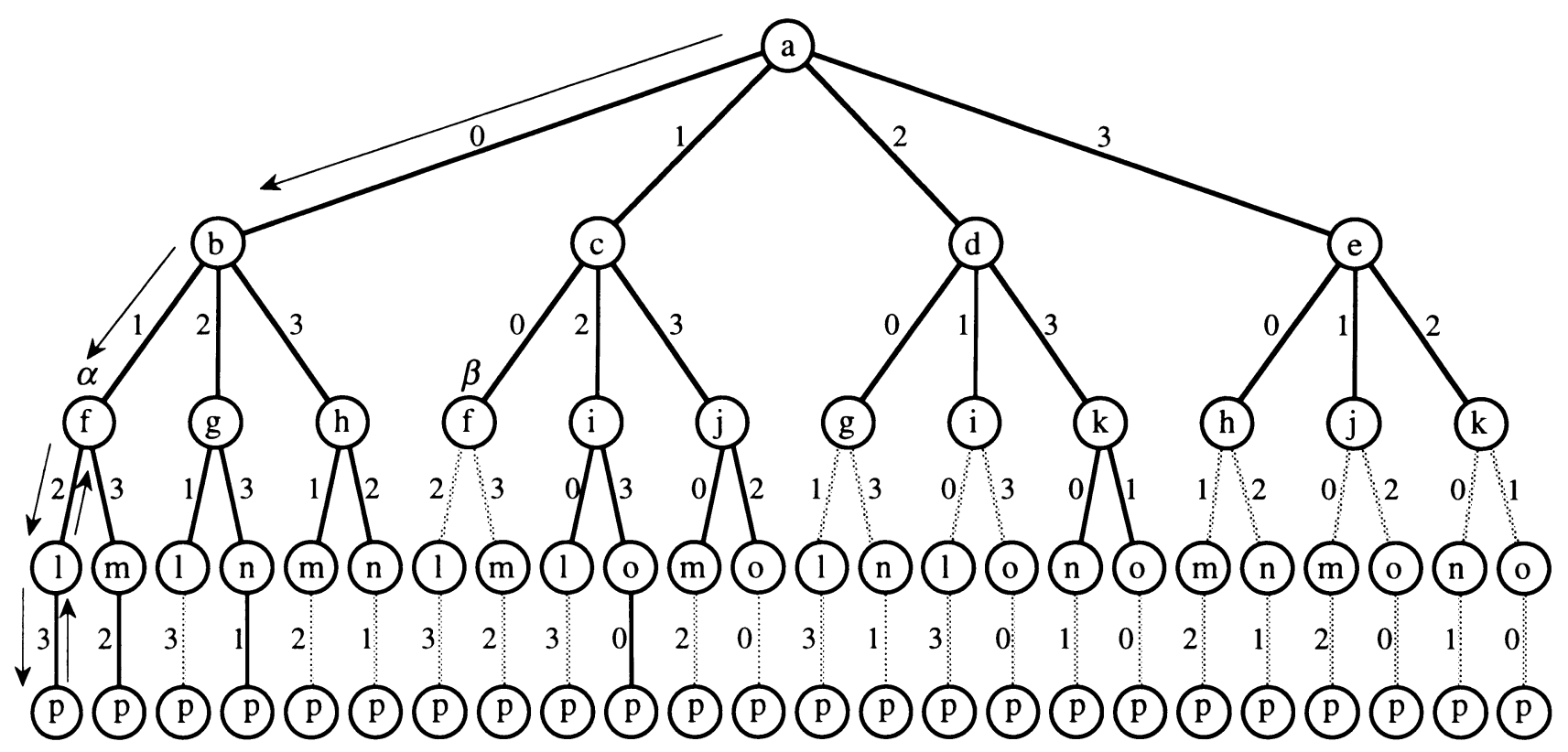

Fig.4 Backward search tree of a sheet metal part with 4 bending portions

\section{3. 曲げ手狛の生成アルココリスム}

板金弊品の曲げ手順を生成するアルゴリズムとしては，蔽品の展 開状態の幾何モデルを入力し、ベンドを一つずつ折り曲げては干涉の 有無を確認し可能な手順を調べる，前向き探索に基づく方法がまず 考えられる. 同じことは，完成状態の幾何モデルのベンドを一つず つひろげ，可能な展開手順を調べる後ろ向き探索でも実現できる. 後ろ向き探索の場合には，得られた手順の逆が曲げ手順となる.

板金彆品では，完成状態に近付くほど狭い空間内にプレートが密 に集まるので，折り曲げや展開の際に干涉が生じやすい。したがつ て後ろ向き探索を採用したほうが, 探索の初期の段階で問題を生じ る手順を検出し破棄できるので効率が良い，そこで以後は，後ろ向 き探索に基づいてすべての展開手順を調べるアルゴリズムについて 議論する.

$n$ 個のベンド $B_{i}, i \in[0, n-1]$ からなる板金製品の全展開手順 は，展開されるべンドが各辺に対応する木槽造で表現できる. 図 $4 に n=4$ の場合の木構造を示す．ただし四中の各辺には，展開さ れるベンド $B_{i}$ の添字のみを示した．木構造の根は製品の完成状態 を表し，末端の節は完全に展開された状態の板金を表す．残りの各 節は，根からその節に至るまでの辺に対応するベンドを順に展開す ることで得られる中間状態の板金を表す．図中の節に付けられてい る記号や辺の淡淡の意味については後述する.

干渉を生じない展開手順を得るには，この木粠造のすべての節 を深さ優先の規則にしたがって探索すればよい（図 4中の矢印参 照），辺を下向きにたどる時には，对応するべンドを展開し自己干 涉や板金と工具の干渉を調べる，もしも干涉が検出された場合に は，展開を中止しその辺以下の節の探索をやめる．逆に辺を上向き にたどる時には，対応するベンドを折り曲げ，展開前の状態を復元 する．木構造の末端の節にたどりついた時，根からその節までの経 路が可能なベンドの展開手順を表す，例えば図の左端の経路は， $B_{0} \rightarrow B_{1} \rightarrow B_{2} \rightarrow B_{3}$ という手順でベンドが展開可能なことを 意味する，以上の処理を繰り返すことで，千渉を生じないすべての
展開手順が得られる.

\section{4. 効率的な干涉判定}

板金モデルのベンドの一つを展開すると, 前述の座標変換の手順 にしたがい，モデルを構成するプレート群がそのベンドの周りを回 転移動する，展開手順を高速に計算するためには，移動するプレー トと他のプレートの衙笑や, プレートと曲げ工具の干渉を効率的に 判定する必要がある.

これらを敞密に判定するには，回転移動するプレートの掃引形状 に相当する立体モテルを生成し, これと他のプレートや工具の立体 モテルの交差を調べればよい，しかし掃引立体の生成には大きな手 間を要するので, この方法は高速な判定には向かない，そこで本研 究では， $\psi=0^{\circ}$ (展開状態) と $\psi=180-\omega^{\circ}$ （折り曲げ状 態) 間の幾つかの離散的な回転角 $\psi$ において, 回転移動したプ レートと他のプレートや工具モデルの交差を調べる, より简易な判 定法を採用した.

\section{1 㙨何的な性分の利用}

板金憋品や曲げ加工の幾何的な性質を利用すると, 干涉判定のた めの手間を以下のように低隇できる.

最後の展開時の判定は不要： 完全に展開された状態の板金のべ ンドを 1 か所だけ曲げる加工では, 加工中にプレート間の衝突 や工具との干渉は生じない.したがって折れ曲がったベンドが 最後に一つだけ残った状態で, そのベンドを展開する作業は必 ず成功するので干渉判定は不要である.

干涉判定すべきプレートの限定： ベンドは板金モテルの木構 造 $\mathcal{S}=(\mathcal{P}, \mathcal{B})$ の辺にあたる. そこで $\mathcal{S}$ からベンド $B_{i}$ を 取り外すことで得られる二つの部分木 $\mathcal{S}_{j}=\left(\mathcal{P}_{j}, \mathcal{B}_{j}\right)$ と $\mathcal{S}_{k}=\left(\mathcal{P}_{k}, \mathcal{B}_{k}\right)$ を考える. $\mathcal{P}_{j}$ は， $B_{i}$ に接続していた 2 枚 のプレートの 1 枚と連結しているプレートの集合を表し， $\mathcal{P}_{k}$ は，もう 1 枚のプレートと連結しているプレートの集合を表 す. $B_{i}$ を展開すると, $\mathcal{P}_{j}$ と $\mathcal{P}_{k}$ はそれぞれまとまって回転 


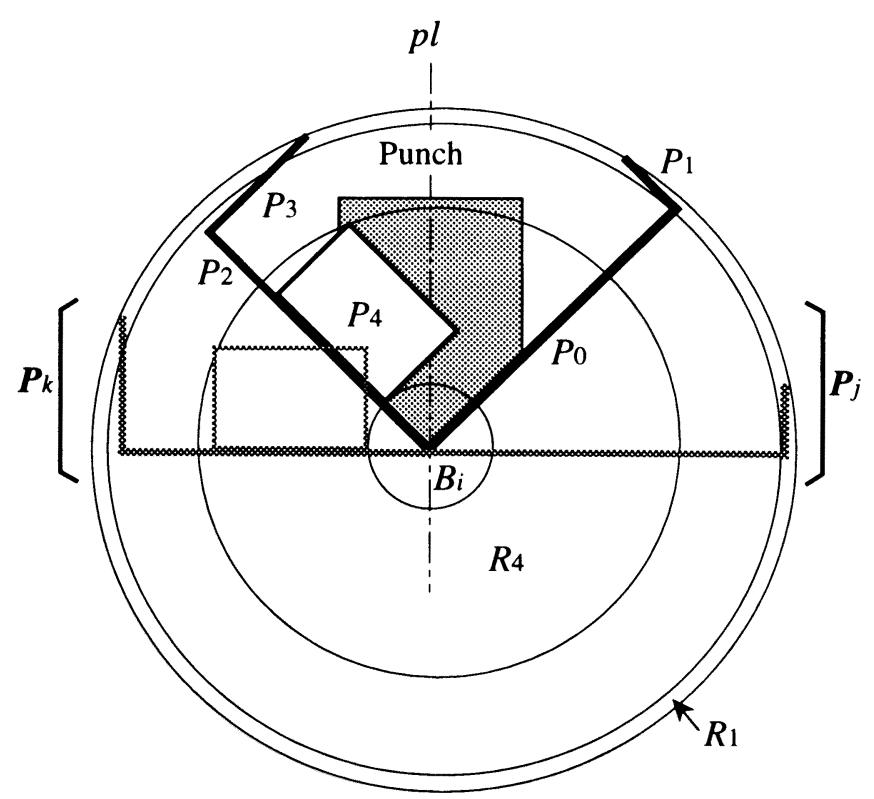

Fig.5 Motion of plates according to a bending operation on $B_{i}$

移動する. したがってこの展開にともなうプレート間の干渉 は， $\mathcal{P}_{j}$ のプレートと $\mathcal{P}_{k}$ のプレートの間でのみ発生する. パンチ中心面に基づくラフチェック：図 5 に、V 字型のパンチ

を用いてベンド $B_{i}$ を折り曲げる様子を示す、ベンドが曲がる につれて， $B_{i}$ の右側に接続するプレートの集合 $\mathcal{P}_{j}$ と, 左側 に接続するプレートの集合 $\mathcal{P}_{k}$ が，両側から回転しつつパンチ の中心面 $p l$ へ接近していく.したがってベンドが完全に折 り曲げられた状態で, $\mathcal{P}_{j}$ と $\mathcal{P}_{k}$ 中の $p l$ を越えないプレート (図 5では, $\mathcal{P}_{j}$ 中の $P_{0}, P_{1}$ と, $\mathcal{P}_{k}$ 中の $P_{2}, P_{3}$ ) は, 曲 げ加工や展開中に互いに干渉することはない.

回転半径に基づくラフチェック：図 5 中のプレート $P_{1}$ と $P_{4}$

は，それぞれ図中の同心のリング状の領域 $R_{1}$ と $R_{4}$ の内部を 移動する. したがってこれらの領域が重なっていなければ, プ レートが干渉することはない，リング領域の重なりは，プレー トの回転半径から容易に判定できる.

\section{2 干涉判定結果の再利用}

図4を見ると，曲げ手順の探索中に同じ干渉判定を何回も繰り返 していることが分かる. たとえば探索木中の記号 $\alpha$ を付した節 は, ベンドを $B_{0} \rightarrow B_{1}$ の順序で展開した状態の板金を表してい る. 一方，同じ段の左から 4 番目の節（記号 $\beta$ を付した）は, ベ ンドを $B_{1} \rightarrow B_{0}$ の順序で展開した板金に対応する． $B_{0}$ を展開 し次に $B_{1}$ を展開しても, 先に $B_{1}$ を展開し次に $B_{0}$ を展開して も，得られる板金の形状は同じである.したがってこれらの状態 で, さらにベンド $B_{2} や B_{3}$ を展開した場合の干渉判定の結果も同 一となる. そこで本研究では, ベンドを展開する際の干渉判定の結 果を記録しておき，以後，幾何的に同一な条件でのベンドの展開が 要求された時には，記録してある判定結果を再利用することで，干 渉判定そのものを省略することにした.

\subsection{1 判定結果の再利用の効果}

図 4に示した展開手順の木構造を用いて, 判定結果の再利用の効 果を検討する．図中の各節には，対応する板金の形状を識別するた めに, a (完成状態) から p (展開状態) までの記号を付した. 板金の形状は，根からその節までの経路に対応する展開済みのベン
ドの組合せにより決まり，展開順序には依存しない，したがってべ ンドの組合せが同一の節には，同一の記号が付けられている．

この木構造を深さ優先で探索する時に，幾何的に同一な条件での ベンドの展開が綝り返される場合の，2回目以降の展開に対応する 辺を灰色で表示した，このような展開では，記録されている過去の 干涉判定の結果が再利用できるので，干渉判定そのものを省略でき る. 過去の判定結果を利用しない時には, 最悪の場合, 図中のすべ ての辺において干涉判定を行うことになるので，その回数は 64 回 となる，一方再利用する場合には，図 4中の実線の辺でのみ干涉判 定が必要となるので, その回数は 32 回となり半隇する.

判定結果の再利用による高速化の度合は，曲げ部の多い複雑な板 金憋品ほど䫓著である. $n$ 個のベンドからなる板金憋品の場合，そ の展開手順の木構造の根を 0 段目とすると， $i$ 段目の節からのびる 辺は合計 $n ! /(n-i-1)$ ! 本となる. 判定結果を再利用しない場 合, 干渉判定の回数 $\mathrm{c}$ は, 木構造の辺の総数と等しいので,

$$
c=\sum_{i=0}^{n-1} \frac{n !}{(n-i-1) !}
$$

となる.

木構造の $i$ 段目における板金の展開状態の種類は, $n$ 個中の $i$ 個 のベンドを展開した場合の数と等しいので $\left(\begin{array}{c}n \\ i\end{array}\right)$ 種類となる. 判定 結果を再利用する場合には，それぞれの状態で残りの $n-i$ 個のへ ンドを展開する際に一度だけ干涉判定を行う。したがって干跦判定 の回数 $c^{\prime}$ は,

$$
c^{\prime}=\sum_{i=0}^{n-1} \frac{n !}{(n-i) ! i !}(n-i)=\sum_{i=0}^{n-1} \frac{n !}{(n-i-1) ! i !}
$$

となる.

$c$ と $c^{\prime}$ の各項を比較すれば, $n>2$ のとき $c>c^{\prime}$ となるこ と，また $n$ がある程度大きくなると， $c$ が $c^{\prime}$ よりもはるかに 大きくなることが分かる. 例えば $n=10$ の板金彆品の場合, $c=9864100$ 回に対して $c^{\prime}=5120$ 回なので, 判定結果を再利 用することで 2000 倍近く高速化されることになる. 実際には， 最後のベンドの展開時の干涉判定は常に不要であり，干涉が検出さ れ探索を途中で止めることも多いのでこれほどの差は開かないが， それでも数十倍の高速化が期待できる.

\subsection{2 判定結果の纪绿法}

最後に判定結果の記録法を検討する. 干涉判定の結果を再利用す るためには，任意の展開状態の板金に関する過去の判定が即座に検 索できればよい，そこで板金モテルの各展開状態に対して，検索の キーとなるユニークなビット列を割り当てることにする.このよう なビット列は, 各ベンドに0から $n-1$ までの番号を与え，展開 済みのベンドの番号に対応するビットには 1 をセットし，それ以外 のビットには 0 をセットすることで生成できる，複雑な板金憋品で も曲げ部の総数はたかだか 10 程度なので，ビット列は 2 バイト用 意すれば十分である.

途中まで展開された状態の板金モデルが与えられたときには，各 ベンドの展開済み / 未展開という情報から上述の手順でビット列を 生成し，これをキーに記録内容を検索する，検索の結果，過去の判 定結果が見つかればそれを再利用する. 見つからない場合には幾何 計算により干渉の有無を判定し、その結果をビット列と関連付け て，将来の再利用のために記䟿しておく． 


\section{5. 曲げ手顺生成プログラム}

議論した手法に基づいて，板金製品の干涉を生じないすべての曲 げ手順を算出するプロクラムを、C 言語を用いて実装した，実際 に幾つかの板金モテルを入力し，その全曲げ手順を自動決定するこ とで提案した手法の有効性を検証した。

図6には，実験に用いた 3 種類の板金製品を示した，開発したプ ログラムを用いて各例題を処理した結果を下表に示す. 表中の最初 の列は例題の曲げ部の数を示し、次の列は算出された曲げ手順の総 数を示す. 3 列目と 4 列目は，それぞれ判定結果を再利用しない場 合と，再利用した場合の処理に要した時間（CPU 秒）を示す。な お計算には， R4600 (100MHz) を CPU とする主記億 $64 \mathrm{MB}$ のSGI Indy ワークステーションを用いた. 最後の列には, 判定 結果の再利用による計算時間短縮の比率を示した。

Table 1 Bending sequence computation results of example parts

\begin{tabular}{c||c|c|c|c|c}
\hline & $\begin{array}{c}\text { Number } \\
\text { of bends }\end{array}$ & $\begin{array}{c}\text { Number } \\
\text { of seq. }\end{array}$ & $\begin{array}{c}\text { Without } \\
\text { record } t_{1}(\mathrm{~s})\end{array}$ & $\begin{array}{c}\text { With record } \\
t_{2}(\mathrm{~s})\end{array}$ & $t_{2} / t_{1}$ \\
\hline $\mathrm{a}$ & 7 & 327 & 26.68 & 5.93 & 0.22 \\
$\mathrm{~b}$ & 8 & 4704 & 386.65 & 23.75 & 0.061 \\
$\mathrm{c}$ & 10 & 1392 & 253.28 & 11.32 & 0.045 \\
\hline
\end{tabular}

これらの結果から、複雑な板金彆品の数千種類にもおよぶ曲げ手 順が、対話的な利用でも支障を感じない程度の時間で計算できるこ と, 過去の判定結果の再利用により計算時間が大幅に短縮できるこ

と、短縮の度合は曲げ部の多いものほど大きいこと，などが分か る.これらの例以外にも, 様々な形状の板金憋品に関して評価実験 を行い，いずれの場合にも満足できる結果を得た.

\section{6. まとめと展高}

本論文では，板金撆品の干涉を生じない全曲げ手順を高速に算出 するアルコリリズムについて議論した．このアルコリズムは，干渉検 出のための幾何計算や干涉判定の回数を低隇することで, 高速な処 理を実現する. 特に過去の干渉判定の結果を再利用することで, 大 幅な高速化を達成した，提案したアルゴリズムに基づいてプログラ ムを作成し、計算実験によりその性能を検証した．このプログラム は, 曲げ部の個数が 10 を越える複雑な板金彆品でも, 対話的な利 用で支障を感じない時間で全曲げ手順を生成できる.

作成したプログラムは, アルコリズムの評価のためのプロトタイ プであり，実用化のためには以下のような課題が残されている.

（1）現状では，V 字型の金型を用いる単純な曲げ加工だけを想 定している. より複雑な加工法も扱えるように, 板金モデルや 干渉の検出手法を昖張する必要がある。

（2）実際の曲げ加エでは，製品の精度や加エコストなども考虑 して, 最適な曲げ手順を決定している. 曲け手順探索の際に,

このような技術的な制約や経済的な制約も評価することで，プ ロクラムの性能の一層の向上が期待できる.

本研究の成果を、板金製品の実用的な工程設計システムや順送金 型の設計支援システムへ発展させたいと考えている.

本研究の一部は, 平成 7 年度の天田金属加工機械技術振興財団の 励研究助成を受けて行われた。関係者各位に深く感謝する。

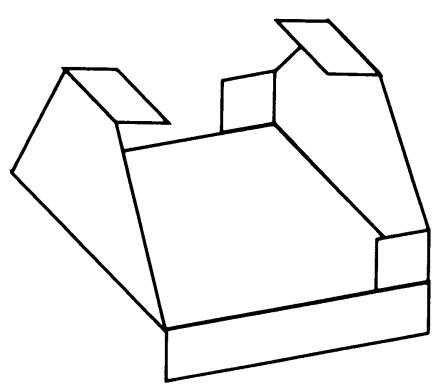

(a)

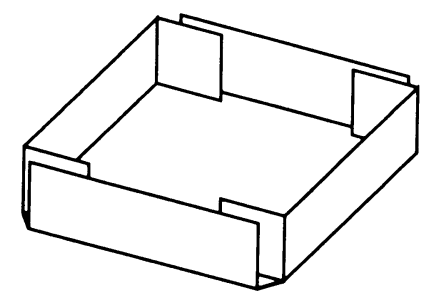

(b)

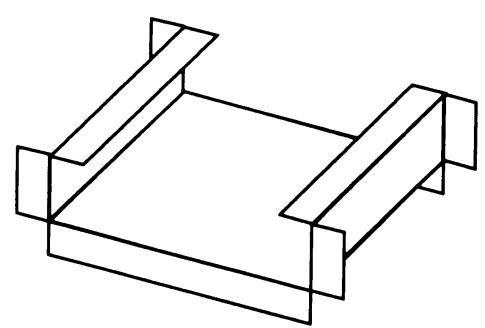

(c)

Fig.6 Example sheet metal parts

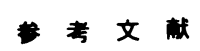

1) D. F. Eary and E. A. Reed: Techniques of Pressworking: Sheet Metal, Prentice-Hall, Englewood Cliffs (1958).

2) M. Inui and F. Kimura: Design of Machining Processes with Dynamic Manipulation of Product Models, in Artificial Intelligence in Design, SpringerVerlag, London (1991) 195.

3) 岡田公治, 渡部举三, 荒井信一, 松崎吉衛, 北沢浩: 板金 $\mathrm{CAD} / \operatorname{COST}$ システムの開発（第 1 報） - システムの権成一, 1995 年度精密工学会秋季大会学術晀演会諈演論文集 (1995) 25.

4) 大久保正雄, 塩川昌男, 三坂浩和: 5 章プレス加工, 自詯車の製造 法, 自動車工学全書 19, 山海堂 (1980) 113 .

5) R. P. Paul: Robot Manipulators: Mathematics, Programming, and Control, The MIT Press, Cambridge (1981).

6) R. Reddy et al.: Symposium on Artificial Intelligence, ACM Computing Surveys, 27, 3 (1995) 301.

7) C. H. Wang and D. A. Bourne: Using Features and Their Constraints to Aid Process Planning of Sheet Metal Parts, Proc. IEEE Int. Conf. Robotics and Automation (1995) 1020.

8) R. H. Wilson and J.-C. Latombe: Geometric Reasoning about Mechanical Assembly, in Algorithmic Foundations of Robotics, A K Peters, Wellesley (1995) 203.

9) 山口文雄: 順送型設計の基礎から応用まで, 型技術, 12, 7 (1997) 98. 